\title{
The Influence of Long-Term and Short-Term Institutional Investors on Complicated Mispricing of Stocks
}

\author{
Bing Liu $\mathbb{D I}^{1,2}$ \\ ${ }^{1}$ School of Economics and Business Administration, Central China Normal University, Wuhan 430079, China \\ ${ }^{2}$ School of Economics and Management, Huainan Normal University, Huainan 232038, China \\ Correspondence should be addressed to Bing Liu; ljane126@126.com
}

Received 20 September 2020; Revised 12 October 2020; Accepted 21 October 2020; Published 10 November 2020

Academic Editor: Ahmed Mostafa Khalil

Copyright (c) 2020 Bing Liu. This is an open access article distributed under the Creative Commons Attribution License, which permits unrestricted use, distribution, and reproduction in any medium, provided the original work is properly cited.

Taking Chinese listed companies from 2009 to 2017 as the research objects, this paper aims at exploring the heterogeneous effect of short-term and long-term institutional investors on stock mispricing. The empirical study finds that long-term institutional investors have an inhibiting effect on stock mispricing, while short-term institutional investors have an opposite effect. When the company information opacity is high, long-term institutional investors have a more obvious inhibiting effect on stock mispricing while short-term institutional investors have a more obvious promoting effect on stock mispricing. When the attention of analysts is enhanced, long-term institutional investors further restrain the stock mispricing while short-term institutional investors further promote the stock mispricing.

\section{Introduction}

When the stock price can reflect the future enterprise profitability correctly, the fluctuations of stock price can guide the resource optimization and reorganization and form a strong supervision on the managers, thus improving the business operation and playing an active role in creating material wealth. However, Chinese stock market has not yet reached semistrong form efficiency [1]. It has the multifractal structure and the long-memory characteristic [2]. The firm-specific information has a low content in stock price [3], and speculation is extremely prominent. The stock mispricing problem is very serious, and the price mechanism is difficult to come into play.

Since the "ultra-convention development of institutional investors" proposed by Chinese regulatory authority in 2000, the number of institutional investors has a rapid growth. The market scale has been expanding, and the market impact has been significant increasingly. Regulatory authority expects institutional investors to adhere to the concept of long-term value investment, rationally hold the stock, and take the initiative to monitor listed companies to promote the healthy development of the stock market. However, due to the fund ranking mechanism, short-term motivation of fund managers, and other practical problems, there is no lack of institutional investors with high turnover rate that frequently trade stocks in order to pursue short-term yields, which enhances the market speculation, increases the market fluctuations, and disrupts the market [4]. Even in the face of the trade war and the new epidemic situation, China still has to unswervingly speed up the financial reform and open up, develop, and expand the financial market, and in this process, the government must adopt various policies and measures to maintain financial stability. Andrew Crockett, former general manager of the bank for International Settlements, believes that an important key requirement for financial stability is that economic entities can trade at a price that reflects the basic factors of the market and that the price will not fluctuate significantly in the short term when the fundamentals do not change. However, many domestic papers, including literature [4], define market volatility by stock price volatility, which leads to an important logic defect: is the volatility moving towards the fundamental direction or the opposite direction (stock mispricing)? If it fluctuates in the direction of fundamentals, it will set things right and is conducive to financial stability; if 
it moves in the direction of opposite fundamentals, stock pricing errors will become more and more serious and the market pricing efficiency will become worse and worse. On the contrary, it will accumulate energy for the financial tsunami, which is not conducive to financial stability. In July 2020, Liu tingjun, President and chief operating officer of Taikang Insurance Group, said that long-term institutional investors are the cornerstone of the stability and efficiency of the capital market. Therefore, a significant research proposition is that what role do long-term institutional investors and short-term institutional investors play in stock mispricing? Whether they are informed traders to promote the information efficiency or speculators to add fuel to the fire? What role do information opacity and attention of analysts play in this? This paper plans to carry out a systematic empirical study on such problems.

This paper first classifies the institutional investors in Chinese stock market based on the characteristics of turnover rate and investigates the effect of short-term and longterm institutional investors on stock mispricing, as well as the impact of information opacity and attention of analysts on the relationship between short-term and long-term institutional investors and stock mispricing. Research shows the following: (1) Long-term institutional investors play a weakening role in stock mispricing, while short-term institutional investors have a completely opposite effect. This is because the informed trading of long-term institutional investors and the role of monitoring listed companies have facilitated the promotion of stock price information amount, while short-term institutional investors are noise traders with incomplete information and bounded rationality. (2) The information opacity of listed companies strengthens the heterogeneous effect of long-term and short-term institutional investors on stock mispricing. When the information opacity is high, the processing attitude and capacity difference of information collection of long-term and shortterm institutional investors lead to a high degree of information asymmetry. Therefore, it further promotes or restrains the stock mispricing. (3) When the attention of analysts is promoted, analysts provide more research reports that include both effective information and optimistic deviation information. Limited to the difference of information discrimination ability and rationality of long-term and short-term institutional investors, long-term institutional investors further restrain the stock mispricing, while shortterm institutional investors further promote the stock mispricing. This study provides Chinese experience for the research on the role of institutional investors in stock mispricing, supports the view that long-term institutional investors and short-term institutional investors have heterogeneous effects on stock mispricing, and analyzes the internal mechanism from the perspective of information.

The main innovations of this paper are as follows: (1) This paper explains the heterogeneous effect of long-term and short-term institutional investors on stock mispricing from the perspective of information and analyzes the influence of different information opacity and information environment on the heterogeneous effect of long-term and short-term institutional investors on stock mispricing and its internal mechanism. (2) This paper uses China's capital market data to study the impact of long-term and short-term institutional investors on stock mispricing. (3) Two methods are used to measure long-term institutional investors and short-term institutional investors. One of them is the innovative design of this paper. The two methods confirm each other, so the empirical results are more robust.

\section{Theoretical Analysis and Research Hypothesis}

Stock trading is essentially an exchange between the current currency and legal claim of future earnings. However, the "future" is uncertain, and many factors, such as enterprise operation, macroeconomic situation, and government policy, affect the future of listed companies and determine the basic value of stocks. The new information of any listed company may reveal the change of the basic value of the stock, and the stock price embodies the reflection of all market participants on their obtained information [5]. The stock market is essentially an information market. Limited by the incomplete information, investors make a misjudgement on the basic value of the stock, which induces the nonrational investment behavior, leads to the stock mispricing, and causes the phenomenon of price distortion in the Chinese stock market. Therefore, in essence, the incomplete information of investors is not entirely the most direct reason of stock mispricing. Many deficiencies in capital market regulations and law enforcement efficacy as well as information collection, transfer, and treatment cost have become sources of incomplete information, resulting in information asymmetry between listed companies and investors and between investors [6].

2.1. Short-Term and Long-Term Institutional Investors and Stock Mispricing. The mechanism of long-term institutional investors on stock mispricing is mainly reflected in the following two points: (1) Long-term institutional investors hold the stock for a long time. They are closer to the information source and more capable of excavating public and private information of listed companies. They use their professional knowledge to analyze the information and can estimate the real value of listed companies, and thus, they are considered as the informed traders. The most direct inhibiting effect of institutional investors on stock mispricing is the informed transaction to transfer information to the market [7]. Once the stock mispricing is found, the informed traders will carry on covered-interest arbitrage for the stock and their trading behavior will transfer information to the investors, which increase the information amount of stock price and promote the return of the stock price to the basic value $[8,9]$. Compared with individual investors, institutions can respond to market public information faster, which reduces the stock price fluctuation and plays a positive role in promoting market information efficiency [10]. To sum up, the informed trading behavior of long-term institutional investors can deliver a signal to the market, which can effectively reduce the incomplete information and 
increase the information amount of stock price, thus restraining the stock mispricing. (2) There is information asymmetry between substantial shareholders and managers of listed companies and investors. They have the moral hazard of exaggerating good news while concealing bad news. Institutional investors have the motivation to actively monitor listed companies [11]. Lu et al. found that companies whose stocks owned by long-term institutional investors such as pension insurance fund, social security fund, and enterprise annuity had less proportion in illegal information disclosure [12]. Niu et al. found that long-term institutional investors had a greater positive impact on voluntary information disclosure [13]. In conclusion, the monitoring activities of long-term institutional investors restrict the financial statements of listed companies, restrain the agency problem from substantial shareholders or management, improve the information disclosure quality, and reduce the incomplete information, thus restraining the stock mispricing.

The mechanism of short-term institutional investors on stock mispricing is mainly reflected in the following two points: (1) Short-term institutional investors do not hold a stock for a long time and their information amount is less than that of long-term institutional investors. They will not carry on field research on listed companies and deeply study the prospects of listed companies like long-term institutional investors. On the one hand, due to the short decisionmaking time of their transactions, there is not enough time to complete the collection of more information. On the other hand, if they conduct a deep investigation and collect information of every stock they plan to buy, they cannot afford the cost. Therefore, the short-term institutional investors have less information with high degree of incomplete information. They cannot form a reasonable expectation and cannot correctly evaluate the enterprise value. Their shareholding and transaction behaviors pull down the information content of stock price, resulting in stock mispricing. (2) The short-term institutional investors pin their hope on buying stocks with low price and selling stocks with high price to obtain the spread return, and their behaviors of frequent transaction, blind follow, and speculation are the typical nonrational speculative behaviors, which has exposed their characteristic of bounded rationality. They are noise traders [14]. Nonrational speculative behaviors of shortterm institutional investors are mainly reflected in the following two points: The first is the positive feedback transaction behavior. DeLong et al. believed that the trading activities of noise traders had a serious impact on stock price fluctuation. The existence of a large number of noise traders will make the stock price form a feedback mechanism, so that the price increasingly deviates from the real value, thus causing the more serious stock mispricing [15]. When a group of institutional investors follow the positive feedback trading strategy, the stock price will deviate from its basic value, resulting in the stock mispricing $[16,17]$. The second is the herd behavior. The herd behavior is a common phenomenon, and there is herd behavior among institutional investors, which is manifested in rushing out to buy or sell a stock at the same time and in the same direction [18]. In the Chinese security market, the herd behavior of institutional investors is even more obvious than that of individual investors [19]. The herd behavior of Chinese institutional investors is a genuine herd behavior that ignores their information, which reduces the information content of stock price [20]. For short-term institutional investors, there is a complex relationship between the incompleteness of information and the irrationality of behavior patterns. They exist and resonate at the same time. The interaction and superposition of the two make the stock mispricing more serious. Based on this, this paper puts forward the following research hypothesis to be tested:

Hypothesis H1: long-term (short-term) institutional investors restrain (promote) the stock mispricing.

\subsection{Information Opacity, Long-Term and Short-Term Insti-} tutional Investors, and Stock Mispricing. When the information opacity of listed companies is high, the content of firm-specific information into the stock price will be less. The less transparent the information, the worse the rationality of stock pricing [3]. When companies have high information opacity, less public information, and more private information, if investors intend to offset the information opacity, they need to pay more costs in manpower and capital to search and analyze information. Long-term institutional investors are willing to pay the information cost, while short-term institutional investors are unwilling and not used to paying the information cost. When the information transparency is high, the information asymmetry is also high. The informed trading and information monitoring of long-term institutional investors are more capable of coming into play, promoting information efficiency, and restraining the stock mispricing. However, short-term institutional investors have more evaluation errors on the enterprise value and are more likely to carry on speculation blindly, which further leads to the stock mispricing.

Hypothesis H2: when the company information opacity is high, long-term (short-term) institutional investors further restrain (promote) the stock mispricing.

2.3. Attention of Analysts, Long-Term and Short-Term Institutional Investors, and Stock Mispricing. Some scholars believed that the securities analysts collected and analyzed information of listed companies and transferred information to the investors through research report, which increased the information propagation speed and information-holding quantity of investors and improved the information environment of investors [21]. Other scholars considered that the research report of securities analysts had an optimistic bias [22]. Reputation anxiety, information homogenization, salary incentive design, and so on induce the herd behavior in the information production of securities analysts, and especially those young analysts who lack experience tend to ignore their private information and imitate or follow senior analysts. Numerous interest conflict factors of institutional investors, extensive operation pattern of the Chinese securities research department, frequent turnover of securities analysts, and reputation anxiety of young analysts, and so on 
are the main causes of the low information content and quality of research reports written by Chinese securities analysts [23]. In conclusion, many securities analysts have issued a lot of research reports, and it cannot be denied that they provide a large amount of information for the market, which also contains some private information. However, there may be a herd behavior among securities analysts, and many of rating reports have an optimistic bias on earnings forecast. The information quality is uneven.

There are differences between long-term and short-term institutional investors in focusing on and using the information provided by securities analysts. First of all, long-term institutional investors have invested in listed companies for a long time and obtained remuneration with the value growth or value return of listed companies. They pay more attention to the information related to the long-term value of listed companies provided by securities analysts. But short-term institutional investors, as short-term speculators, pay more attention to information related to the short-term trend provided by security analysts. Secondly, long-term institutional investors are informed traders, and it is extremely important for the accuracy of value judgement of listed companies. Therefore, they must carry on comparative study on the private information collected by themselves and information provided by securities analysts, carefully review the real private information, and incorporate these information into their self-owned information. Short-term institutional investors will not take a lot of cost to collect private information, and its information holding quantity is even lower than that of securities analysts. They lack discriminating ability of the information provided by securities analysts. They also know that securities analysts may have an optimistic bias. Their solution is to see whether the rating of security analysts has consistency. If so, short-term institutional investors will believe that the rating opinion is reliable. However, the consensus of securities analysts may be the herd behavior formed by mutual imitation, which is not the reflection of private information consistency [24]. Furthermore, short-term institutional investors are shortsighted. They do not focus on whether the consistent-rating adjustment of securities analysts is based on private information or herd behavior. They are more concerned about whether reports of analysts can provide them with positive feedback trading opportunities. Perhaps, the security analysts have actually found the "gold mine." Perhaps, they just tell a story. As long as more and more investors believe in the story and buy stocks, they will have positive feedback in trading opportunities. The herd behavior of securities analysts will aggravate the herd behavior of institutional investors, so for short-term institutional investors, they find the opportunity and participate in the herb behavior earlier and they will be in a more favorable position in this bubble game.

To sum up, in the face of incomplete information market where real information, false information, and noise are intertwined, short-term institutional investors lack the discrimination ability of information quality of securities analysts. Attention of analysts cannot improve the information quality of short-term institutional investors and even the nonrational emotion of securities analysts can be transferred to the short-term institutional investors. More and more attention of securities analysts may mean the production of herd behavior of securities analysts, which can aggregate the herd behavior of short-term institutional investors on the contrary, thus further promoting the stock mispricing. Long-term institutional investors have tracked listed companies for a long time. They master a large amount of public and private information of listed companies and have the discrimination ability of optimistic bias of securities analysts. The research reports of securities analysts accelerate the propagation velocity of private information from listed companies to long-term institutional investors and increase the information holding quantity of long-term institutional investors, thus promoting the inhibiting effect of long-term institutional investors on stock mispricing. Based on this, this paper puts forward the following research hypothesis to be tested.

Hypothesis $\mathrm{H} 3$ : when the attention of analysts is higher, long-term (short-term) institutional investors further restrain (promote) the stock mispricing.

\section{Research Design}

3.1. Sample Selection and Data Source. The shareholding data of institutional investors are derived from RESSET financial database. According to the fund-type classification standard of Morningstar investment, the monetary funds, bond funds, principal-protected funds, and other types of funds are removed, and only stock funds and hybrid funds are retained. This paper takes listed companies from 2009 to 2017 in stock markets of Shanghai and Shenzhen as the samples and eliminates samples in financial industry and samples with missing value. The financial data come from the CSMAR database and the data of market value and attention of analysts are derived from the Wind database. The industry classification takes Industry Classification in 2012 issued by China Securities Regulatory Commission as the criterion.

\subsection{Variable Definition}

3.2.1. Measurement of Long-Term and Short-Term Institutional Investors. This paper draws lessons from the research ideas of the existing literature, carefully sorts out the microshareholding information of all institutional investors at the end of each year, and adopts two approaches to divide institutional investors into long-term institutional investors and short-term institutional investors.

The first approach uses the transaction of institutional investors in the past two years as a standard for dividing long-term investors and short-term investors [25]. Before the use of this approach, due to the existence of stock dividend, increase by transferring, and other behaviors of listed companies, the number of stocks held by institutional investors in different periods has no comparability. Therefore, the adjustment factor of capital stock is firstly used to adjust the number of stocks, and amounts of buying and 
selling stocks of institutional investors are calculated. The computational formula is as follows:

$$
\begin{aligned}
\text { CR_buy }_{k, t} & =\sum_{i=1}^{M_{k}}\left(N_{k, i, t}-N_{k, i, t-1}\right) P_{i, t}\left|1_{\left|N_{k, i, t}>N_{k, i, t-1}\right|}\right| \\
\text { CR_sell } & =\sum_{k, t} M_{k}\left(N_{k, i, t}-N_{k, i, t-1}\right) P_{i, t}\left|1_{\left|N_{k, i, t}<N_{k, i, t-1}\right|}\right|
\end{aligned}
$$

Among them, $P_{i, t}$ is the price of stock $i$ in the $t$ year. $N_{k, i, t}$ and $N_{k, i, t-1}$ are the number of the stock $i$ of institutional investor $k$ in the $t$ year and $t-1$ year after the adjustment of capital stock adjustment factor. $M_{k}$ indicates the number of types of shareholding of institutional investors $k$. $1_{\left|N_{k, i, t}>N_{k, i, t-1}\right|}$ is the indicative function. When $N_{k, i, t}>N_{k, i, t-1}$, $1_{\left|N_{k, i, t}>N_{k, i, t-1}\right|}=1$. Otherwise, $1_{\left|N_{k, i, t}>N_{k, i,-1}\right|}=0$. The indicative function indicates that the number of stocks $i$ held by institutional investor $k$ in the $t$ year is large than that in the $t-1$ year. Therefore, it can be considered that this institutional investor has bought the stocks of this company in the $t$ year, and this indicative function indicates that the transaction direction of institutional investor is the stock purchase. Similarly, it can be seen that the transaction direction of $1_{\left|N_{k, i, t}>N_{k, i, t-1}\right|}$ is the stock sale. CR_buy $k_{k, t}$ indicates the total amount of stock purchase of institutional investor $k$ in the $t$ year and CR_sell $k, t$ indicates the total amount of stock sale of institutional investor $k$ in the $t$ year. The turnover rate of institutional investor $k$ in the $t$ year is expressed as follows:

$$
\mathrm{CR}_{k, t}=\frac{2 \min \left(\text { CR_buy }_{k, t}, \text { CR_sell }_{k, t}\right)}{\sum_{i=1}^{N_{k}} N_{k, i, t} P_{i, t}+N_{k, i, t-1} P_{i, t-1}} .
$$

Therefore, it is assumed that the turnover rate of institutional investor $k$ in the $t$ year is the average turnover rate in the past two years:

$$
\mathrm{AVG}_{-} \mathrm{CR} 1_{k, t}=\frac{1}{2} \sum_{j=0}^{1} \mathrm{CR}_{k, t-j} .
$$

The second approach draws lessons from the two indicators proposed by Bushee to measure the shareholding turnover rate of institutional investors $[26,27]$, which are the proportion of continuous shareholding of institutional investors in the net asset value of institutional investors for two consecutive years (STAB) and the turnover rate of investment portfolio of institutional investors (PT):

$$
\begin{aligned}
\operatorname{STAB}_{k, t} & =\frac{\sum_{i=1}^{M_{k}} w_{k, i, t} \mathrm{LT}_{k, i, t}}{\sum_{i=1}^{M_{k}} w_{k, i, t}}, \\
\mathrm{PT}_{k, t} & =\frac{\sum_{i=1}^{M_{k}}\left|\Delta w_{k, i, t}\right|}{\sum_{i=1}^{M_{k}} w_{k, i, t}+\sum_{i=1}^{M_{k}} w_{k, i, t-1}} .
\end{aligned}
$$

Among them, $w_{k, i, t}$ and $w_{k, i, t-1}$ are the proportion of the stock $i$ value held by institutional investor $k$ in its total net value in the $t$ year and $t-1$ year, respectively. $M_{k}$ indicates the number of shareholding types of institutional investor $k$. When institutional investor $k$ holds the stock $i$ in the $t-1$ year and $t$ year, $\mathrm{LT}_{k, i, t}=1$. Otherwise, $\mathrm{LT}_{k, i, t}=0 .\left|\Delta \mathrm{w}_{k, i, t}\right|$ is equal to the absolute value of $\mathrm{w}_{k, i, t}$ and $\mathrm{w}_{k, i, t-1}$, which indicates the proportion deviation of stock value $i$ held by institutional investor $k$ in the $t-1$ year and $t$ year.

Then, this paper carries out the normative approach for these two indicators. Here, the author adopts the most commonly used $z$-score standardized method:

$$
X_{k, t}^{*}=\frac{X_{k, t}-\bar{X}_{t}}{S_{t}} .
$$

This formula is used to carry out the normative approach for $\mathrm{STAB}_{k, t}$ and $\mathrm{PT}_{k, t}$, and $\mathrm{STAB}_{k, t}^{*}$ and $\mathrm{PT}_{k, t}^{*}$ are obtained. Because $\mathrm{STAB}_{k, t}^{*}$ is the backward indicator of turnover rate, the larger its value, the lower the turnover rate. Therefore, this paper uses the method of multiplying by -1 to carry out backward processing for $\mathrm{STAB}_{k, t}^{*}$. The mean values of above two indicators are taken, and the turnover rate of institutional investor $k$ in the $t$ year can be obtained:

$$
\mathrm{AVG}_{-} \mathrm{CR} 2_{k, t}=\frac{1}{2}\left(\mathrm{PT}_{k, t}^{*}-\mathrm{STAB}_{k, t}^{*}\right) \text {. }
$$

The high turnover rate represents the frequent transaction of the institutional invest and the short average shareholding time, which indicates that it is a short-term institutional investor. The low turnover rate shows that the institutional investor have held the stock for a long time, which indicates that it is a long-term institutional investor. This paper ranks the institutional investors in every year according to the indicator of turnover rate. Those in the bottom third are defined as long-term institutional investors (LIO), and those in the top third are defined as short-term institutional investors (SIO). Based on the design idea of institutional investor variable proposed by Borochin and Yang, the proportions $p \mathrm{LIO} 1_{i, t}$ and $p \mathrm{LIO} 2_{i, t}$ of long-term institutional investors are obtained by calculating the number of long-term institutional investors of the $i$ stock in the $t$ year according to the above two classification methods, respectively. Similarly, the proportions $p \mathrm{SIO}_{i, t}$ and $p \mathrm{SIO} 2_{i, t}$ of short-term institutional investors can be obtained.

3.2.2. Measurement of Stock Mispricing. This paper draws lessons from the method of Rhodes-Kropf et al.[27] to measure the stock mispricing [28]. This method mainly uses the enterprise financial information to estimate the intrinsic value of the enterprise and compares it with the market price, so as to obtain the deviation degree between the enterprise market price and intrinsic value. First of all, the book-to-market ratio is used for the decomposition model. The logarithm of book-to-market ratio is decomposed to the mispricing at the enterprise level in theory. The detail is as follows: 


$$
\begin{aligned}
\mathbf{m}_{i, t}-b_{i, t} & =\operatorname{Dev}_{i, t}^{\text {Firm }}+\operatorname{Dev}_{i, t}^{\text {Ind }}+\text { Growth }_{i, t} \\
& =\underbrace{\left[m_{i, t}-v\left(\theta_{i t} ; \alpha_{j t}\right)\right]}_{\text {enterprise }}+\underbrace{\left[v\left(\theta_{i t} ; \alpha_{j t}\right)-v\left(\theta_{i t} ; \alpha_{j}\right)\right]}_{\text {industry }}+\underbrace{\left[v\left(\theta_{i t} ; \alpha_{j}\right)-b_{i, t}\right]}_{\text {real growth opportunities of enterprises }} .
\end{aligned}
$$

Among them, $\mathbf{m}_{i, t}$ takes the natural logarithm of the market value of enterprise $i$ in the $t$ year and $b_{i, t}$ takes the natural logarithm of the total assets of enterprise $i$ in the $t$ year. Therefore, after taking natural logarithm, the book-tomarket ratio can be represented as $\mathbf{m}_{i, t}-b_{i, t} . v\left(\theta_{i t} ; \alpha_{j t}\right)$ indicates the current intrinsic value of the enterprise in the $t$ year based on the calculation of $j$ industry, of which $\theta_{i t}$ indicates the relevant financial information of enterprise $i$ in the $t$ year and $\theta_{i t}$ represents the long-term intrinsic value of enterprise based on the calculation of $j$ industry. Model (7) separates the stock mispricing at the enterprise level $\left(\operatorname{Dev}_{i, t}^{\text {Firm }}\right)$, mispricing at the industry level $\left(\operatorname{Dev}_{i, t}^{\text {Ind }}\right)$, and real growth opportunity of the enterprise $\left(\mathrm{Growth}_{i, t}\right)$ by mathematical processing.

A linear regression model is established for enterprises according to different periods $(t)$ and industries $(j)$, so as to estimate the intrinsic value of enterprises. The model is expressed as follows:

$$
\begin{aligned}
\mathbf{m}_{i, t}= & \alpha_{0 j t}+\alpha_{1 j t} b_{i, t}+\alpha_{2 j t} \ln (\mathrm{NI})_{i, t}^{+}+\alpha_{3 j t} I_{(<0)} \ln (\mathrm{NI})_{i, t}^{+} \\
& +\alpha_{4 j t} \mathrm{LEV}_{i, t}+\varepsilon_{i t} .
\end{aligned}
$$

Among them, $(\mathrm{NI})_{i, t}^{+}$indicates the absolute value of the net margin of enterprise $i$ in the $t$ year and $I_{(<0)}$ represents the indicative function when the net margin of enterprise $i$ in the $t$ year is negative (When $\mathrm{NI} \geq 0, I=0$ and when $\mathrm{NI}<0, I=1$ ). $\mathrm{LEV}_{i, t}$ represents the lever ratio of enterprise $i$ in the $t$ year, which is obtained by total liabilities divided by total assets. Therefore, as shown in Model (9), the estimated value of current intrinsic value $\left(v\left(\theta_{i t} ; \alpha_{j t}\right)\right)$ of enterprise $i$ in the $t$ year is equal to the estimated value of explained variable $\mathbf{m}_{i, t}$ in Model (8):

$$
\begin{aligned}
v\left(\theta_{i t} ; \widehat{\alpha}_{j t}\right)= & \widehat{\alpha}_{0 j t}+\widehat{\alpha}_{1 j t} b_{i, t}+\widehat{\alpha}_{2 j t} \ln (\mathrm{NI})_{i, t}^{+} \\
& +\widehat{\alpha}_{3 j t} I_{(<0)} \ln (\mathrm{NI})_{i, t}^{+}+\widehat{\alpha}_{4 j t} \mathrm{LEV}_{i, t} .
\end{aligned}
$$

Then, the residual in Model (8) is obtained through calculation, thus obtaining the mispricing at the enterprise level $\left(\operatorname{Dev}_{i, t}^{\text {Firm }}\right) . \operatorname{Dev}_{i, t}^{\text {Firm }}=0$ indicates that the stock price perfectly embodies the basic value. $\operatorname{Dev}_{i, t}^{\text {Firm }}>0$ shows that the stock price overestimates the basic value and the larger value indicates more serious overestimation of basic value. $\operatorname{Dev}_{i, t}^{\text {Firm }}<0$ shows that the stock price underestimates the basic value and the lower value indicates more serious underestimation of basic value.

On this basis, this paper selects two indicators to measure the stock mispricing. One is the absolute stock mispricing (Misval), that is $\left|\operatorname{Dev}_{i, t}^{\text {Firm }}\right|$, which is used to measure the absolute deviation degree of stock price to the basic value. The other is the stock price overestimation (Overval), that is, $I_{(>0)} \operatorname{Dev}_{i, t}^{\text {Firm }}$, the positive value of $\operatorname{Dev}_{i, t}^{\text {Firm }}$ is retained to measure the positive deviation degree of stock price to the basic value. The selection of these two indicators is mainly based on the following considerations: first, whether the stock price is higher than the basic value or lower than the stock value, Misval can measure the absolute level of the deviation; second, the issue of institutional investors causing the stock price to be overvalued is more concerned by the market and more prominent, so Overval is set.

3.2.3. Control Variable. This paper draws lessons from practice of Borochin and Yang [28] and the following 6 variables are selected as control variables [29]: Company scale (lnTA): the larger the company scale, the more complete the information disclosure system. This paper selects the natural logarithm of the total assets of the enterprise to measure the company scale. Shareholding ratio of institutional investors ( $\mathrm{pINST}$ ): this paper mainly studies the effect of long-term and short-term institutional investors on stock mispricing, not the role of institutional investors in stock mispricing. The common influence of institutional investors on stock mispricing can be eliminated by putting the shareholding ratio of institutional investors into the control variables, so as to better observe the heterogeneous effects of long-term institutional investors or short-term institutional investors on stock mispricing. In this paper, the shareholding ratio of tradable circulation A-shares of institutional investors is selected as the proxy variable of the shareholding ratio of institutional investors. HHI (INSThhi): this variable measures the ownership concentration and reflects the degree of stock equity competition. In this paper, the quadratic sum of the shareholding ratio of the top 10 shareholders in tradable circulation A-shares is selected as the proxy variable of HHI. Altman $Z$ Score ( $Z$ _Score): this variable is the proxy variable of the financial health condition of listed companies, which is expressed as $(1.2 \times$ working capital $+1.4 \times$ retained income $+3.3 \times$ earnings before interest and tax $+0.999 \times$ sales $) /$ total assets. Long-term debt ratio (Lev): the variable is used to control the influence of capital structure, which is expressed as longterm liability/total assets. Cash flow volatility (CFdisp): it is used to control the influence of cash flow volatility on the stock mispricing, which is expressed as standard deviation of cash flow in recent three years/mean value of cash flow in recent three years.

3.3. Model Design. First, the role of long-term and shortterm institutional investors on the stock mispricing $\left(Y_{i, t}\right)$ is studied, which is used to test the hypothesis H1. The specific model is shown as follows: 


$$
\begin{aligned}
Y_{i, t}= & \alpha+\beta_{1} p \mathrm{Type}_{i, t-1}+\beta_{2} \ln T A_{i, t-1}+\beta_{3} \text { INST }_{i, t-1} \\
& +\beta_{4} \mathrm{INSThhi}_{i, t-1}+\beta_{5} Z_{-} \mathrm{Score}_{i, t-1}+\beta_{6} \mathrm{Lev}_{i, t-1} \\
& +\beta_{7} \mathrm{CFdisp}_{i, t-1}+\mathrm{fe}_{t}+\mathrm{fe}_{j}+\varepsilon_{i, t} .
\end{aligned}
$$

The explaining variable pType here refers to the proportion of long-term institutional investors or short-term institutional investors. In order to solve the endogenous problem, both explaining variables and control variables lag one phase. Because macrofactors and industry factors will affect stock mispricing, this paper also adds time fixed effect to control the influence of macro factor, and adds industry fixed effect to control the influence of industry factors.

Secondly, accounting earning is the most important firm-specific information and the earnings management level of company reflects the degree of nontransparency of company information (Hutton et al., 2009). Therefore, taking example by the practice of Hutton et al., this paper uses the absolute value of operational accruals of company (absDisAcc) to measure the information opacity of company:

$$
\begin{aligned}
\frac{\mathrm{TAC}_{i, t}}{\mathrm{TA}_{i, t-1}}= & \alpha_{1} \frac{1}{\mathrm{TA}_{i, t-1}}+\alpha_{2} \frac{\Delta \mathrm{REV}_{i, t}}{\mathrm{TA}_{i, t-1}}+\alpha_{3} \frac{\mathrm{PPE}_{i, t}}{\mathrm{TA}_{i, t-1}}+\varepsilon_{i, t}, \\
\operatorname{absDisAcc}= & \mid \frac{\mathrm{TAC}_{i, t}}{\mathrm{TA}_{i, t-1}}-\left(\widehat{\alpha}_{1} \frac{1}{\mathrm{TA}_{i, t-1}}+\widehat{\alpha}_{2} \frac{\Delta \mathrm{REV}_{i, t}-\Delta \mathrm{REC}_{i, t}}{\mathrm{TA}_{i, t-1}}\right. \\
& \left.+\widehat{\alpha}_{3} \frac{\mathrm{PPE}_{i, t}}{\mathrm{TA}_{i, t-1}}\right) \mid .
\end{aligned}
$$

Among them, TAC is the total accruals, which is equal to the operating profit minus the net cash flow generated from operating activities; TA is the total assets; $\triangle \mathrm{REV}$ is the increase in sales revenue; $\triangle$ REC is the increase in accounts receivable; and PPE is the original value of fixed assets.

This paper groups the information opacity based on the median, divides samples into the group with high information opacity and the group with low information opacity, and carries out regression analysis for the use model of these two subsamples (10), so as to test the hypothesis $\mathrm{H} 2$.

Thirdly, in order to test the hypothesis $\mathrm{H} 3$, this paper introduces the cross-product term of proportion of institutional investors and attention of analysts, of which attention of analysts (NumEst) uses the number of rating institutions as the proxy variable. The specific model is as follows:

$$
\begin{aligned}
Y_{i, t}= & \alpha+\beta_{1} p \text { Type }_{i, t-1}+\beta_{2} p \text { Type }_{i, t-1} \times \text { NumEst }_{i, t-1} \\
& +\beta_{3} \text { NumEst }_{i, t-1}+\beta_{4} \operatorname{lnTA}_{i, t-1}+\beta_{5} \text { PINST }_{i, t-1} \\
& +\beta_{6} \mathrm{INSThhi}_{i, t-1}+\beta_{7} Z_{-} \text {Score }_{i, t-1}+\beta_{8} \text { Lev }_{i, t-1} \\
& +\beta_{9} \text { CFdisp }_{i, t-1}+\mathrm{fe}_{t}+\mathrm{fe}_{j}+\varepsilon_{i, t} .
\end{aligned}
$$

\section{Empirical Results}

4.1. Descriptive Statistical Analysis. Table 1 reports the descriptive statistical analysis result of the whole sample. As can be seen from Table 1, there are some differences in the statistical indicators of the proportion of long-term and short-term institutional investors under the two methods. The mean of $p \mathrm{LIO} 1$ is $6.64 \%$ lower than that of $p \mathrm{LIO} 2$, and their dispersion coefficients are 0.77 and 0.76 , respectively, and the difference is very small; the mean of pSIO1 is $13.48 \%$ higher than that of $p \mathrm{SIO} 2$, and their dispersion coefficients are 0.99 and 1.05 , respectively, and the difference is very small. And the average ratio of short-term institutional investors is lower than that of long-term institutional investors by $34.62 \%-46.22 \%$.

This paper calculates the median of proportion of longterm and short-term institutional investors. ispLIO1 $=1$ or ispLIO2 $=1$ indicates that the proportion of long-term institutional investors reaches the above level of median, while ispSIO1 $=1$ or ispSIO2 $=1$ indicates that the proportion of short-term institutional investors reaches the above level of median. Table 2 reports the mean of each indicator for these four subsamples. A large proportion of a kind of institutional investors shows that such institutional investors prefer to buy this type of stocks. From Table 2, it can seen that the information opacity and cash flow volatility of the long-term institutional investors group are lower than that of the shortterm institutional investors group. The company scale of the long-term institutional investors group is greater than that of the short-term institutional investors group, and attention of analysts and shareholding ratio of institutional investors of the long-term institutional investors group are approximately equal to that of the short-term institutional investors group. To sum up, long-term institutional investors prefer companies that with large company scale, low cash flow volatility, and high information transparency while shortterm institutional investors are the opposite.

\subsection{Regression Analysis}

4.2.1. Long-Term and Short-Term Institutional Investors and Stock Mispricing. The relevant empirical results are reported in Table 3. This paper uses F test and Hausman test to select the most suitable model among fixed effect model, linear mixture regression model, and random effect model. For the original hypothesis $\mathrm{H} 0$, it is seen that for $\mathrm{ui}=0$, the $\mathrm{F}$ test strongly rejects the original hypothesis, which indicates that the fixed effect model is superior to the linear mixture regression model, and each stock should be allowed to have its own intercept term. The Hausman test strongly rejects the original hypothesis, which shows that the fixed effect model rather than the random effect model should be used. Thus, this paper selects to use the fixed effect model to test the relationship between long-term and short-term institutional investors and stock mispricing. The same test has been carried out in the following models, and the test results show that the fixed effect model is the most suitable in this paper. 
Table 1: Descriptive statistics.

\begin{tabular}{|c|c|c|c|c|c|c|}
\hline Variable & Sample size & Mean & Standard deviation & Lower quartile & Median & Upper quartile \\
\hline Overval & 21390 & 0.167 & 0.281 & 0 & 0 & 0.247 \\
\hline Misval & 21390 & 0.334 & 0.274 & 0.129 & 0.271 & 0.470 \\
\hline pLIO1 & 19538 & 0.309 & 0.239 & 0.118 & 0.286 & 0.483 \\
\hline pLIO2 & 19538 & 0.331 & 0.253 & 0.125 & 0.313 & 0.500 \\
\hline pSIO1 & 19538 & 0.202 & 0.200 & 0.0360 & 0.167 & 0.308 \\
\hline pSIO2 & 19538 & 0.178 & 0.187 & 0.0230 & 0.140 & 0.258 \\
\hline pINST & 18707 & 0.195 & 0.198 & 0.0420 & 0.122 & 0.295 \\
\hline INSThhi & 19794 & 0.0870 & 0.114 & 0.00400 & 0.0370 & 0.133 \\
\hline $\ln \mathrm{TA}$ & 21339 & 21.97 & 1.331 & 21.04 & 21.80 & 22.71 \\
\hline Z_Score & 21303 & 1.187 & 6.121 & 0.844 & 1.285 & 1.747 \\
\hline Lev & 21163 & 0.0890 & 0.372 & 0.00900 & 0.0390 & 0.125 \\
\hline CFdisp & 18344 & 0.138 & 55.15 & 0.110 & 0.469 & 1.069 \\
\hline NumEst & 21390 & 17.16 & 21.99 & 1 & 8 & 25 \\
\hline absDisAcc & 18307 & 0.0800 & 0.205 & 0.0220 & 0.0490 & 0.0930 \\
\hline
\end{tabular}

TABLE 2: Group descriptive statistics.

\begin{tabular}{lcccc}
\hline Variable & $\begin{array}{l}(1) \\
\text { ispLIO1 }=1\end{array}$ & $\begin{array}{c}(2) \\
(3) \\
\text { ispLIO2 }=1\end{array}$ & ispSIO1=1 & 0.216 \\
pINST & 0.208 & 0.210 & 0.215 & 0.0720 \\
INSThhi & 0.112 & 0.112 & 21.84 & 21.86 \\
lnTA & 22.61 & 22.61 & 1.403 & 1.401 \\
Z_Score & 1.306 & 1.320 & 0.0720 & 0.0730 \\
Lev & 0.104 & 0.104 & 0.665 & 0.579 \\
CFdisp & 0.121 & 0.124 & 22.00 & 21.47 \\
NumEst & 21.54 & 21.72 & 0.0820 & 0.0790 \\
absDisAcc & 0.0710 & 0.0730 & & \\
\hline
\end{tabular}

TABLE 3: Long-term and short-term institutional investors and stock mispricing.

\begin{tabular}{|c|c|c|c|c|c|c|c|c|}
\hline Variable & $\begin{array}{c}\text { (1) } \\
\text { Overval }\end{array}$ & $\begin{array}{c}(2) \\
\text { Misval }\end{array}$ & $\begin{array}{c}\text { (3) } \\
\text { Overval }\end{array}$ & $\begin{array}{c}(4) \\
\text { Misval }\end{array}$ & $\begin{array}{c}(5) \\
\text { Overval }\end{array}$ & $\begin{array}{c}(6) \\
\text { Misval }\end{array}$ & $\begin{array}{c}(7) \\
\text { Overval }\end{array}$ & $\begin{array}{c}(8) \\
\text { Misval }\end{array}$ \\
\hline pLIO1 & $\begin{array}{c}-0.0391^{* * *} \\
(0.00955)\end{array}$ & $\begin{array}{c}-0.0380^{* * *} \\
(0.0109)\end{array}$ & & & & & & \\
\hline pLIO2 & & & $\begin{array}{c}-0.0508^{* * *} \\
(0.00921)\end{array}$ & $\begin{array}{c}-0.0417^{* * *} \\
(0.0105)\end{array}$ & & & & \\
\hline pSIO1 & & & & & $\begin{array}{c}0.0481^{* * *} \\
(0.0104)\end{array}$ & $\begin{array}{l}0.0224^{*} \\
(0.0118)\end{array}$ & & \\
\hline pSIO2 & & & & & & & $\begin{array}{c}0.0363^{* * *} \\
(0.0108)\end{array}$ & $\begin{array}{c}0.0168 \\
(0.0123)\end{array}$ \\
\hline $\begin{array}{l}\text { Control } \\
\text { variable }\end{array}$ & Under control & Under control & Under control & Under control & Under control & Under control & Under control & Under control \\
\hline Time effect & Under control & Under control & Under control & Under control & Under control & Under control & Under control & Under control \\
\hline $\begin{array}{l}\text { Industrial } \\
\text { effect }\end{array}$ & Under control & Under control & Under control & Under control & Under control & Under control & Under control & Under control \\
\hline Sample size & 13,726 & 13,726 & 13,726 & 13,726 & 13,726 & 13,726 & 13,726 & 13,726 \\
\hline$R^{2}$ & 0.027 & 0.016 & 0.028 & 0.016 & 0.027 & 0.015 & 0.026 & 0.015 \\
\hline F test & $7.58^{* * *}$ & $4.28^{* * *}$ & $7.59^{* * *}$ & $4.28^{* * *}$ & $7.66^{* * *}$ & $4.27^{* * *}$ & $7.65^{* * *}$ & $4.27^{* * *}$ \\
\hline $\begin{array}{l}\text { Hausman } \\
\text { test }\end{array}$ & $527.91^{* * *}$ & $102.95^{* * *}$ & $947.71^{* * *}$ & $103.00^{* * *}$ & $291.96^{* * *}$ & $95.92^{* * *}$ & $406.87^{* * *}$ & $102.34^{* * *}$ \\
\hline
\end{tabular}

Symbols ${ }^{*},{ }^{* *}$, and ${ }^{* * *}$ represent that they are significant at the level of $10 \%, 5 \%$ and $1 \%$, respectively.

There is no more detailed description in the following passage.

What needs to be added is that the fixed effect model increases individual effect, but it does not conflict with time fixed effect and industry fixed effect and will not lead to the decline of the effectiveness of the regression model in this paper.

As can be seen from Table 3, regressions 1 and 3 use Overval as the proxy variable of overestimated stock price, while regressions 2 and 4 take Misval as the proxy variable 
of absolute stock mispricing. After controlling the influence of shareholding ratio of institutional investors, ownership concentration, and other factors, the coefficients of proportion indicators PLIO1 and pLIO2 of longterm institutional investors are $-0.0391,-0.0508,-0.0380$, and -0.0417 , respectively, and are significant at the level of $1 \%$, which supports the hypothesis H1. This shows that long-term institutional investors have an inhibiting effect on absolute stock mispricing and price overestimation, and increasing the proportion of long-term institutional investors is conducive to the improvement of market efficiency. Long-term institutional investors monitor the information disclosure of listed companies, and as informed traders, their shareholding behavior accelerates the efficiency of information flow, increases the information quantity of stocks, and restrains the stock mispricing. Regressions 5 to 8 test the influence of increasing the proportion of short-term institutional investors on absolute stock mispricing and price overestimation, with coefficients of $0.0481,0.0224,0.0363$, and 0.0168 , respectively, of which two of them are significant at the level of $1 \%$ and one of them are significant at the level of $10 \%$. Only pSIO2 has no significant impact on Misval, which basically supports the hypothesis H1. Short-term institutional investors have short shareholding time, and they prefer to adopt the positive feedback transaction strategy to obtain short-term gains. They have less private information and are short-sighted noise traders. Their speculative behavior promotes the absolute stock mispricing and price overestimation and facilitates the speculative atmosphere of the Chinese stock market, which leads to the severe stock market fluctuation.

4.2.2. Information Opacity, Long-Term and Short-Term Institutional Investors, and Stock Mispricing. The test results of hypothesis $\mathrm{H} 2$ are shown in Tables 4 and 5 . The following can be observed: (1) The coefficients of long-term institutional investors are negative, and they are significant at the level of $1 \%$ when the information opacity is high. But there are two nonsignificant coefficients when the information opacity is low and there is only one coefficient which is significant at the level of $10 \%$. (2) The coefficients of short-term institutional investors are positive, and they are all significant when the information opacity is high, but only one of them is significant when the information opacity is low. This provides sufficient evidence to support hypothesis $\mathrm{H} 2$; that is, when the company information opacity is high, the deviation is high between long-term institutional investors and average market information holding quantity and their shareholding behavior further promote the improvement of information quantity of stock price, thus further restraining the stock mispricing. When the company information opacity is high, there is a greater difference between information holding quantity of shortterm institutional investors and actual company information, which leads to a larger deviation of basic stock value estimation, thus further promoting the stock mispricing.
4.2.3. Attention of Analysts, Long-Term and Short-Term Institutional Investors, and Stock Mispricing. The test results of hypothesis $\mathrm{H} 3$ are shown in Table 6. The following can be observed: The coefficients of cross-product terms of the proportion of long-term institutional investors and the attention of analysts are negative, and they are significant at the significance level of $1 \%$. (2) The coefficients of crossproduct terms of the proportion of short-term institutional investors and the attention of analysts are positive, and they are all significant at the significant level of $1 \%$. The hypothesis $\mathrm{H} 3$ is verified; that is, when the attention of analysts is improved, the long-term institutional investors further restrain the absolute stock mispricing and price estimation, while the short-term institutional investors further promote the absolute stock mispricing and price estimation.

The verification of hypothesis $\mathrm{H} 3$ sufficiently indicates that the influence of analysts on the relationship of longterm and short-term institutional investors and stock mispricing is heterogeneous. Long-term institutional investors are the owners of public and private information. After obtaining the information provided by analysts, long-term institutional investors conduct survey, analysis, and discrimination by themselves, extract valuable information, and abandon the information of optimistic bias, thus increasing the information updating speed of long-term institutional investors, increasing their information holding quantity and further restraining the stock mispricing. Shortterm institutional investors do not have private information. They lack the discrimination ability of analyst information and cannot identify whether analysts have positive bias and degree of optimism bias. They are short-sighted, and they may not care much about whether there is information deviation of analysts. They are concerned about the immediate impact of analyst information on the market, especially the influence on the speculative behavior of noise traders mainly relying on individual investors. Therefore, the increase of attention of analysts has provided them with more positive feedback trading opportunities on the contrary, which further promotes the stock mispricing.

Generally speaking, the higher the analyst's attention is, the stronger the heterogeneous effect of long-term and short-term institutional investors on stock mispricing. That is to say, the analyst's attention plays a catalytic role.

4.3. Robustness Test. Two classification methods are used to calculate the proportion of long-term and short-term institutional investors. However, considering the fact that the number of shareholding can also reflect the attitude of institutional investors, this paper still uses these two classification methods in the robustness test and calculates the number of shareholding of long-term institutional investors for the $i$ stock in the $t$ year and the proportion of the number of shareholding of all institutional investors, thus obtaining the shareholding ratios of long-term institutional investors LIO $_{i, t}$ and $p \mathrm{LIO}_{i, t}$. Similarly, the shareholding ratios of short-term institutional investors $p \mathrm{SIO}_{i, t}$ and $p \mathrm{SIO} 4_{i, t}$ are calculated. Model (10) is also used for regression after replacing the explaining variable. As shown in Table 7, 


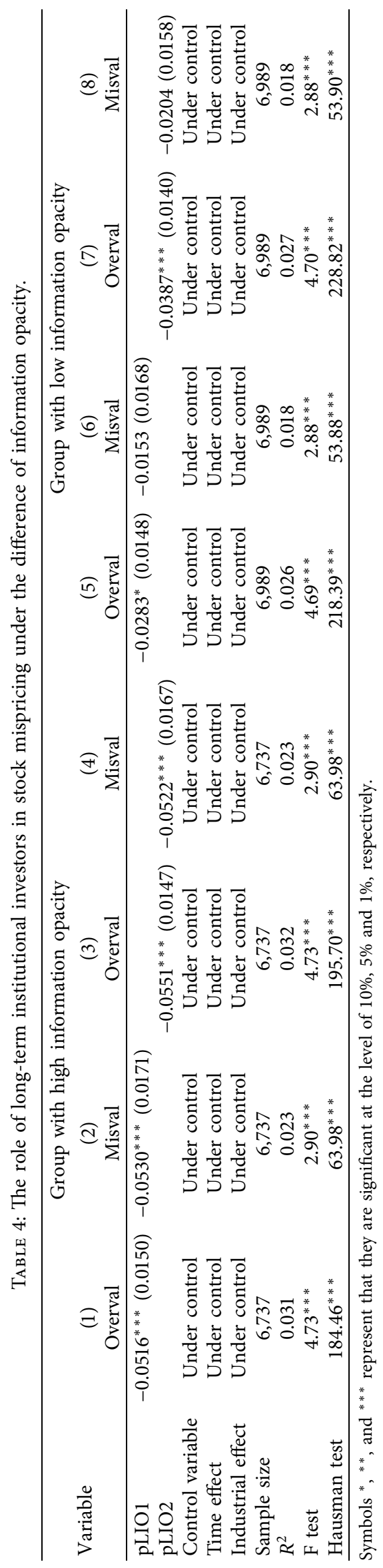




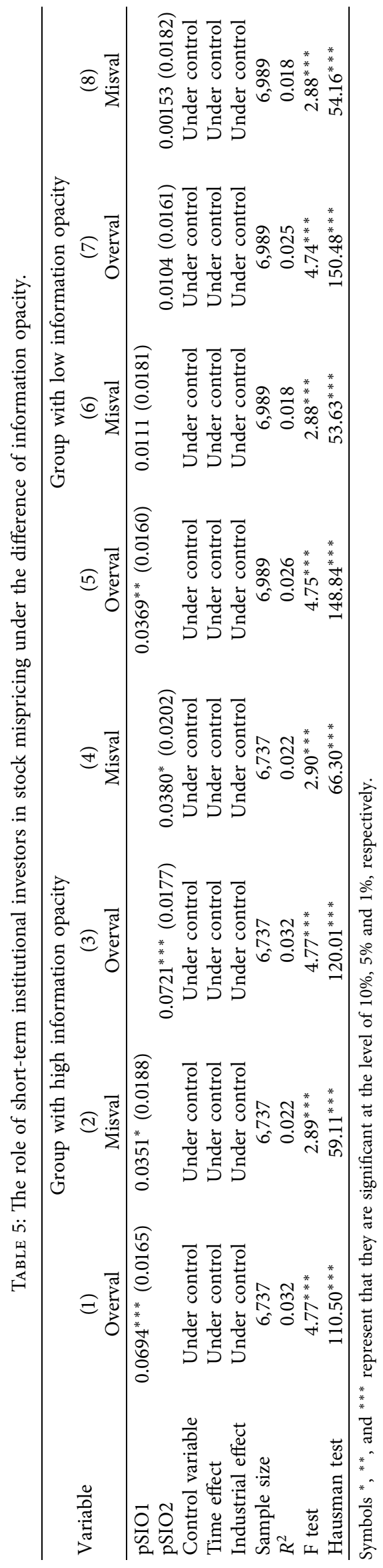


TABLE 6: The role of long-term and short-term institutional investors in stock mispricing under the attention of analysts.

\begin{tabular}{|c|c|c|c|c|c|c|c|c|}
\hline Variable & $\begin{array}{c}(1) \\
\text { Overval }\end{array}$ & $\begin{array}{c}(2) \\
\text { Misval }\end{array}$ & $\begin{array}{c}\text { (3) } \\
\text { Overval }\end{array}$ & $\begin{array}{c}(4) \\
\text { Misval }\end{array}$ & $\begin{array}{c}\text { (5) } \\
\text { Overval }\end{array}$ & $\begin{array}{c}(6) \\
\text { Misval }\end{array}$ & $\begin{array}{c}\text { (7) } \\
\text { Overval }\end{array}$ & $\begin{array}{c}(8) \\
\text { Misval }\end{array}$ \\
\hline pLIO1 & $\begin{array}{c}-0.00217 \\
(0.0108)\end{array}$ & $\begin{array}{l}-0.0110 \\
(0.0124)\end{array}$ & & & & & & \\
\hline pLIO1 $\times$ NumEst & $\begin{array}{c}-0.00336^{* * *} \\
(0.000521)\end{array}$ & $\begin{array}{c}-0.00269^{* * *} \\
(0.000593)\end{array}$ & & & & & & \\
\hline pLIO2 & & & $\begin{array}{l}-0.0167 \\
(0.0106)\end{array}$ & $\begin{array}{l}-0.0146 \\
(0.0120)\end{array}$ & & & & \\
\hline pLIO2 $\times$ NumEst & & & $\begin{array}{c}-0.00292^{* * *} \\
(0.000481)\end{array}$ & $\begin{array}{c}-0.00251^{* * *} \\
(0.000548)\end{array}$ & & & & \\
\hline pSIO1 & & & & & $\begin{array}{l}0.00955 \\
(0.0121)\end{array}$ & $\begin{array}{c}-0.00474 \\
(0.0137)\end{array}$ & & \\
\hline pSIO1 $\times$ NumEst & & & & & $\begin{array}{r}0.00379 * * * \\
(0.000681)\end{array}$ & $\begin{array}{l}0.00300^{* * *} \\
(0.000776)\end{array}$ & & \\
\hline pSIO2 & & & & & & & $\begin{array}{c}-0.000329 \\
(0.0124)\end{array}$ & $\begin{array}{l}-0.0114 \\
(0.0142)\end{array}$ \\
\hline pSIO2 $\times$ NumEst & & & & & & & $\begin{array}{l}0.00396^{* * *} \\
(0.000693)\end{array}$ & $\begin{array}{l}0.00318^{* * *} \\
(0.000790)\end{array}$ \\
\hline NumEst & $\begin{array}{l}0.00199 * * * \\
(0.000223)\end{array}$ & $\begin{array}{c}0.000908^{* * *} \\
(0.000253)\end{array}$ & $\begin{array}{l}0.00195^{* * *} \\
(0.000227)\end{array}$ & $\begin{array}{c}0.000947^{* * *} \\
(0.000258)\end{array}$ & $\begin{array}{c}0.000099 \\
(0.000207)\end{array}$ & $\begin{array}{c}-0.000575^{* *} \\
(0.000236)\end{array}$ & $\begin{array}{c}0.000227 \\
(0.000193)\end{array}$ & $\begin{array}{c}-0.000491^{* *} \\
(0.000220)\end{array}$ \\
\hline Control variable & $\begin{array}{l}\text { Under } \\
\text { control }\end{array}$ & $\begin{array}{l}\text { Under } \\
\text { control }\end{array}$ & $\begin{array}{l}\text { Under } \\
\text { control }\end{array}$ & $\begin{array}{l}\text { Under } \\
\text { control }\end{array}$ & $\begin{array}{l}\text { Under } \\
\text { control }\end{array}$ & $\begin{array}{l}\text { Under } \\
\text { control }\end{array}$ & $\begin{array}{l}\text { Under } \\
\text { control }\end{array}$ & $\begin{array}{l}\text { Under } \\
\text { control }\end{array}$ \\
\hline Time effect & $\begin{array}{l}\text { Under } \\
\text { control }\end{array}$ & $\begin{array}{l}\text { Under } \\
\text { control }\end{array}$ & $\begin{array}{l}\text { Under } \\
\text { control }\end{array}$ & $\begin{array}{l}\text { Under } \\
\text { control }\end{array}$ & $\begin{array}{l}\text { Under } \\
\text { control }\end{array}$ & $\begin{array}{l}\text { Under } \\
\text { control }\end{array}$ & $\begin{array}{l}\text { Under } \\
\text { control }\end{array}$ & $\begin{array}{l}\text { Under } \\
\text { control }\end{array}$ \\
\hline Industrial effect & $\begin{array}{l}\text { Under } \\
\text { control }\end{array}$ & $\begin{array}{l}\text { Under } \\
\text { control }\end{array}$ & $\begin{array}{l}\text { Under } \\
\text { control }\end{array}$ & $\begin{array}{l}\text { Under } \\
\text { control }\end{array}$ & $\begin{array}{l}\text { Under } \\
\text { control }\end{array}$ & $\begin{array}{l}\text { Under } \\
\text { control }\end{array}$ & $\begin{array}{l}\text { Under } \\
\text { control }\end{array}$ & $\begin{array}{l}\text { Under } \\
\text { control }\end{array}$ \\
\hline Sample size & 13,726 & 13,726 & 13,726 & 13,726 & 13,726 & 13,726 & 13,726 & 13,726 \\
\hline$R^{2}$ & 0.033 & 0.017 & 0.034 & 0.018 & 0.033 & 0.016 & 0.032 & 0.016 \\
\hline F test & $7.04^{* * *}$ & $4.27^{* * *}$ & $7.05^{* * *}$ & $4.27^{* * *}$ & $7.17^{* * *}$ & $4.26^{* * *}$ & $7.17^{* * *}$ & $4.26^{* * *}$ \\
\hline Hausman test & $1022.78^{* * *}$ & $146.44^{* * *}$ & $1192.62^{* * *}$ & $180.80^{* * *}$ & $534.78^{* * *}$ & $122.52^{* * *}$ & $479.47^{* * *}$ & $128.00^{* * *}$ \\
\hline
\end{tabular}

Symbols $*{ }^{* *}$, and ${ }^{* * *}$ represent that they are significant at the level of $10 \%, 5 \%$ and $1 \%$, respectively.

TABLE 7: Shareholding of long-term and short-term institutional investors and stock mispricing.

\begin{tabular}{|c|c|c|c|c|c|c|c|c|}
\hline Variable & $\begin{array}{c}(1) \\
\text { Overval }\end{array}$ & $\begin{array}{c}(2) \\
\text { Misval }\end{array}$ & $\begin{array}{c}(3) \\
\text { Overval }\end{array}$ & $\begin{array}{c}(4) \\
\text { Misval }\end{array}$ & $\begin{array}{c}(5) \\
\text { Overval }\end{array}$ & $\begin{array}{c}(6) \\
\text { Misval }\end{array}$ & $\begin{array}{c}(7) \\
\text { Overval }\end{array}$ & $\begin{array}{c}(8) \\
\text { Misval }\end{array}$ \\
\hline pLIO3 & $\begin{array}{l}-0.0146^{*} \\
(0.00787)\end{array}$ & $\begin{array}{c}-0.0195^{* *} \\
(0.00885)\end{array}$ & & & & & & \\
\hline pLIO4 & & & $\begin{array}{c}-0.0222^{* * *} \\
(0.00691)\end{array}$ & $\begin{array}{c}-0.0220^{* * *} \\
(0.00815)\end{array}$ & & & & \\
\hline pSIO3 & & & & & $\begin{array}{c}0.0248^{* * *} \\
(0.00734)\end{array}$ & $\begin{array}{c}0.0109 \\
(0.00825)\end{array}$ & & \\
\hline pSIO4 & & & & & & & $\begin{array}{c}0.0213^{* * *} \\
(0.00795)\end{array}$ & $\begin{array}{c}0.0103 \\
(0.00919)\end{array}$ \\
\hline $\begin{array}{l}\text { Control } \\
\text { variable }\end{array}$ & $\begin{array}{l}\text { Under } \\
\text { control }\end{array}$ & Under control & Under control & Under control & $\begin{array}{l}\text { Under } \\
\text { control }\end{array}$ & $\begin{array}{l}\text { Under } \\
\text { control }\end{array}$ & $\begin{array}{l}\text { Under } \\
\text { control }\end{array}$ & $\begin{array}{l}\text { Under } \\
\text { control }\end{array}$ \\
\hline Time effect & $\begin{array}{l}\text { Under } \\
\text { control }\end{array}$ & Under control & Under control & Under control & $\begin{array}{l}\text { Under } \\
\text { control }\end{array}$ & $\begin{array}{l}\text { Under } \\
\text { control }\end{array}$ & $\begin{array}{l}\text { Under } \\
\text { control }\end{array}$ & $\begin{array}{l}\text { Under } \\
\text { control }\end{array}$ \\
\hline $\begin{array}{l}\text { Industrial } \\
\text { effect }\end{array}$ & $\begin{array}{l}\text { Under } \\
\text { control }\end{array}$ & Under control & Under control & Under control & $\begin{array}{l}\text { Under } \\
\text { control }\end{array}$ & $\begin{array}{l}\text { Under } \\
\text { control }\end{array}$ & $\begin{array}{l}\text { Under } \\
\text { control }\end{array}$ & $\begin{array}{l}\text { Under } \\
\text { control }\end{array}$ \\
\hline Sample size & 13,726 & 13,726 & 13,726 & 13,726 & 13,726 & 13,726 & 13,726 & 13,726 \\
\hline$R^{2}$ & 0.025 & 0.015 & 0.026 & 0.015 & 0.026 & 0.015 & 0.026 & 0.015 \\
\hline F test & $7.60^{* * *}$ & $4.27^{* * *}$ & $7.68^{* * *}$ & $4.28^{* * *}$ & $7.65^{* * *}$ & $4.27^{* * *}$ & $7.63^{* * *}$ & $4.27^{* * *}$ \\
\hline $\begin{array}{l}\text { Hausman } \\
\text { test }\end{array}$ & $265.42^{* * *}$ & $100.04^{* * *}$ & $430.26^{* * *}$ & $102.18^{* * *}$ & $294.19^{* * *}$ & $96.09^{* * *}$ & $269.00^{* * *}$ & $105.69^{* * *}$ \\
\hline
\end{tabular}

Symbols ${ }^{*},{ }^{* *}$, and ${ }^{* * *}$ represent that they are significant at the level of $10 \%, 5 \%$ and $1 \%$, respectively. 
long-term institutional investors still significantly restrain the absolute stock mispricing and price overestimation, while short-term institutional investors also significantly promote the overestimation of stock price.

The reason why the short-term institutional investors fail to significantly promote the absolute mispricing of stocks may be that the short-term institutional investors fail to significantly promote the stock price to be more undervalued when considering the number of shares held. Combined with Table 7 and Table 3, considering that four kinds of proxy variables of long-term institutional investors, shortterm institutional investors, and two kinds of proxy variables of stock mispricing are used in this paper, the regression results of short-term and long-term institutional investors on stock mispricing are robust.

\section{Conclusion}

With the increase of the number and scale of institutional investors, the investment behavior of institutional investors has been continuously divided. This paper, based on the characteristics of turnover rate, divides institutional investors into long-term institutional investors and short-term institutional investors. Taking listed companies from 2009 to 2017 in stock markets of Shanghai and Shenzhen as the research objects, this paper discusses the role of different types of institutional investors on stock mispricing.

Through empirical study, the following are found: (1) With the increase of the proportion of long-term institutional investors, the stock mispricing is significantly reduced, which conforms to the hypothesis that long-term institutional investors serve as the informed traders and monitor the information disclosure of listed companies. With the increase of the proportion of short-term institutional investors, the degree of stock mispricing is significantly increased, which is in line with the hypothesis that short-term institutional investors serve as noise traders. (2) When the company information opacity is high, the information quantity of stock price is low and the degree of information asymmetry is high. At that time, the shareholding and transaction behavior of long-term institutional investors can improve the information efficiency more effectively, while the short-term institutional investors have more significant deviation in company value and show stronger irrational speculative behavior, which disrupts the effectiveness of market pricing. (3) When the attention of analysts is improved, the degree of company information asymmetry of the company is not effectively relieved but slightly increased. The reason is that long-term institutional investors have better discrimination ability of identifying analyst reports with uneven information quality compared with short-term institutional investors, while short-term institutional investors are more significantly influenced by herd behavior of analysts. (4) In the process of long-term or short-term institutional investors' influence on stock mispricing, information quality, information cognition, and information environment play a significant role, as shown in Figure 1.

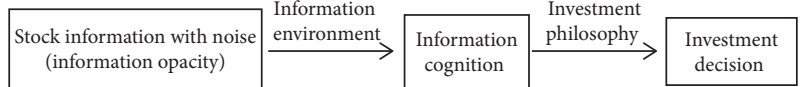

FIgURE 1: Information transfer process in investment decision of institutional investors.

Different from mature market, domestic institutional investors attach great importance to short-term performance ranking indicator, which directly results in frequent changes of domestic fund managers and short-term investment objectives. The proportion of domestic individual investors is far greater than that in the mature market, as well as imperfect supervision rules of national capital market also provide the growing soil for the nonrational behaviors of short-term institutional investors. The important significance of this paper aims at revealing the heterogeneous effect of long-term institutional investors on the stock mispricing and the significant role of information environment in it. The regulatory authority should take effective measures to restrain the short-term speculative behavior of institutional investors, guide the long-term rational investment thinking of institutional investors, make greater efforts to introduce long-term rational funds to enter the market, and optimize the structure of investors, thus giving full play to the role of resource allocation of capital market. The regulatory authority should also strengthen the monitoring of information disclosure of listed companies, analyst reports, and other information production and spreading links, improve the information completeness of listed companies, and reduce the degree of information asymmetry between investors, so as to effectively restrain the nonrational behavior of investors and promote market stability.

There are complex and intertwined influences among institutional investors, between institutional investors and listed companies, and between institutional investors and securities analysts, forming a complex topological relationship. There may be a strong effect of strong links between individuals, such as the strong link between fund managers and star securities analysts, which will change the investment strategies of institutional investors; or there may be a strong effect of weak links. Perhaps, the analysis report of an unknown securities analyst read by the fund manager inadvertently or the subtle investment signals of other funds on the market will suddenly promote so that institutional investors can reexamine their investment strategies. Therefore, this paper believes that it will be a very meaningful research direction to further study the heterogeneous effects of short-term and long-term institutional investors on stock mispricing by using topological structure theory.

\section{Data Availability}

No data were used to support this study.

\section{Conflicts of Interest}

The author declares that there are no conflicts of interest. 


\section{Acknowledgments}

This work was supported by the Key Projects of Anhui Outstanding Young Talents Support Program (gxyqZD2020100).

\section{References}

[1] B. Zhang and X. M. Li, "Asymptotically efficient study of Chinese stock market," Economic Research, no. 1, pp. 54-94, 2003.

[2] C. Y. Han, Y. M. Wang, and Y. Ning, "Analysis and comparison of the multifractality and efficiency of Chinese stock market: evidence from dynamics of major indexes in different boards," Physica A: Statistical Mechanics and Its Applications, vol. 45, no. 5, pp. 1-18, 2019.

[3] Y. P. Wang, H. L. Liu, and L. S. Wu, "Information transparency, institutional investors and stock price synchronism," Journal of Financial Research, vol. 42, no. 12, pp. 162-174, 2009.

[4] J. J. Liu and H. P. Xu, "Institutional investors: long-term investors or short-term opportunists?" Journal of Financial Research, vol. 55, no. 9, pp. 141-154, 2012.

[5] R. Lu and L. B. Xu, "A study on the unbalanced response of Chinese stock market to policy information," China Economic Quarterly, vol. 4, no. 1, pp. 319-330, 2004.

[6] L. Y. Zhai, "Information, investor behavior and capital market efficiency," Economic Research, vol. 50, no. 3, pp. 47-54, 2004.

[7] S. J. Grossman, "On the impossibility of informationally efficient markets," American Economic Review, vol. 70, no. 3, pp. 393-408, 1980.

[8] A. R. Admati and P. Pfleiderer, "A monopolistic market for information," Journal of Economic Theory, vol. 39, no. 2, pp. 400-438, 1986.

[9] S. Chakravarty, "Stealth-trading: which traders' trades move stock prices?" Journal of Financial Economics, vol. 61, no. 2, pp. 289-307, 2001.

[10] Y. Hou and D. Y. Ye, "Institutional investors, informed trading and market efficiency: the empirical evidence from Chinese capital market," Journal of Financial Research, vol. 51, no. 4, pp. 131-145, 2008.

[11] J. J. Mcconnell and H. Servaes, "Additional evidence on equity ownership and corporate value," Journal of Financial Economics, vol. 27, no. 2, pp. 595-612, 1990.

[12] Y. Lu, Y. J. Zhu, and X. Y. Hu, "An empirical study on institutional investor's ownership and violation of listed companies," Nankai Management Review, vol. 15, no. 1, 2012.

[13] J. B. Niu, C. Wu, and S. N. Li, "Institutional investor types, stock equity characteristics and voluntary information disclosure," Management Review, vol. 25, no. 3, 2013.

[14] Y. Zhang and H. W. Zhang, "The formation and supervision of stock market information and stock market bubble," Economic System Reform, vol. 20, no. 6, 2002.

[15] J. B. De Long, A. Shleifer, L. H. Summers et al., "Noise trader risk in financial markets," Journal of Political Economy, vol. 98, 1990.

[16] H. Hong and J. C. Stein, "Differences of opinion, short-sales constraints, and market crashes," Review of Financial Studies, vol. 16, no. 2, pp. 487-525, 2003.

[17] K. Daniel, D. Hirshleifer, and A. Subrahmanyam, "Investor psychology and security market under- and overreactions," Journal of Finance, vol. 53, no. 6, 1998.
[18] H. Chen, "An empirical study on herd behavior of institutional investors in Chinese stock market," Nankai Economic Research, vol. 20, no. 2, pp. 91-94, 2004.

[19] Z. W. Li, P. K. Yu, and J. Yang, "The difference of herd behavior between institutional investors and individual investors," Journal of Financial Research, vol. 53, no. 11, pp. 77-89, 2010.

[20] N. X. Xu, S. Y. Yu, and Z. H. Yi, "The herd behavior of institutional investors and stock price collapse risk," Management World, vol. 29, no. 7, pp. 31-43, 2013.

[21] L. D. BrownR. L. Hagerman et al., "An evaluation of alternative proxies for the market's assessment of unexpected earnings," Journal of Accounting and Economics, vol. 9, no. 2, pp. 1-193, 1987.

[22] S. Mola and M. Guidolin, "Affiliated mutual funds and analyst optimism," Journal of Financial Economics, vol. 93, no. 1, pp. 108-137, 2009.

[23] Q. F. Cai and J. Chen, "Why do securities analysts repeat the market information- the empirical test and treatment discussion based on market response," Chinese Industrial Economy, vol. 28, no. 7, pp. 140-149, 2011.

[24] X. Yan and Z. Zhang, "Institutional investors and equity returns: are short-term institutions better informed?" Review of Financial Studies, vol. 22, no. 2, pp. 893-924, 2009.

[25] B. J. Bushee, "The influence of institutional investors on myopic R\&D investment behavior," The Accounting Review, vol. 73, no. 3, pp. 305-333, 1998.

[26] B. J. Bushee, "Do institutional investors prefer near-term earnings over long-run value?" Contemporary Accounting Research, vol. 18, no. 2, pp. 207-246, 2001.

[27] M. Rhodes-Kropf, S. Viswanathan, and D. T. Robinson, Valuation Waves and Merger Activity: The Empirical Evidence, Social Science Electronic Publishing, Rochester, NY, USA, 2005.

[28] P. Borochin and J. Yang, "The effects of institutional investor objectives on firm valuation and governance," Journal of Financial Economics, vol. 88, no. 3, pp. 171-199, 2017.

[29] A. M. Kozae, A. A. El Atik, A. Elrokh, and M. Atef, "New types of graphs induced by topological spaces," Journal of Intelligent \& Fuzzy Systems, vol. 36, no. 6, 2019. 